\title{
Pesan Dakwah dalam Film 99 Cahaya di Langit Eropa (Studi Semiotika terhadap Film Karya Guntur Soeharjanto)
}

\author{
Nasruddin \& Ach Zulfikar Ali \\ zulfikar@idia.ac.id \\ IDIA Prenduan Sumenep
}

\begin{abstract}
Movie is one of the most effective tools for da'wah in present time and also in future. Regardless of its drawbacks and advantages, it is the mass media that plays important role in influencing and shaping public opinion. It molds public opinion through its contents. Among the most phenomenal movies is '99 Cahaya di Langit Eropa'. This movie contains strong messages of da'wah, yet it also has the contrary. This study aims to investigate da'wah messages in this movie, both verbal and non-verbal. Two parts of this movie are analyzed. This study is a qualitative study. It employs Roland Barthes semiotics theory to analyze the denotation, connotation and myth in the movie. Data are collected through documentation and library research. Results show that this movie presents values and messages of da'wah Islam. The messages delivered include aqidah, shariah,
\end{abstract}


94-122 | Nasruddin \& Ach Zulfikar Ali

and akhlaq. It also conveys messages answering contemporary issues in da'wah such as negative stigma of non-Muslim about hijab and polygamy. On the other hand, the movie also has a non-verbal message that appears contradictory to da'wah messages, camel hump hijabstyle.

Keywords: da'wah, movies '99 Cahaya di Langit Eropa'

\begin{abstract}
Abstrak Film merupakan salah satu media yang sangat efektif untuk dijadikan media dakwah alternatif untuk masa kini dan akan datang. Dengan segala kelebihan dan kekurangannya, paling tidak ia merupakan salah satu media komunikasi massa ini memilik banyak peran dalam mempengaruhi dan membentuk masyarakat berdasarkan muatan dibaliknya. Salah satu film yang cukup fenomenal adalah film 99 Cahaya di Langit Eropa. Film ini sarat dengan pesan-pesan dakwah tetapi juga terdapat beberapa pesan yang tidak mengandung pesan dakwah. Kajian ini dilakukan untuk mengetahui pesan-pesan dakwah secara verbal dan non verbal dalam film 99 Cahaya di Langit Eropa yang terdiri dari 2 part. Kajian ini menggunakan metode penelitian kualitatif dengan pendekatan analisis semiotika Roland Barthes untuk mengetahui makan denotatif, konotatif dan mitos yang terdapat dalam film tersebut. Teknik pengumpulan data dilakukan dengan cara dokumentasi dan studi kepustakaan (library research). Hasil penelitian menunjukkan bahwa dalam Film 99 Cahaya di Langit Eropa merupakan film yang merepresentasikan nilai dan pesan dakwah Islamiyah. Pesan pesan dakwah tersebut dikategorikan menjadi 3 macam, pertama pesan dakwah yang berkaitan dengan nilai aqidah, syariah dan akhlak. Selain itu juga terdapat pesan mengenai permasalahan dakwah Islam kontemporer yaitu, menjawab stigma negatif non muslim terkait jilbab dan poligami, serta terdapat satu pesan non verbal yang kontradiktif dengan pesan dakwah (model jilbab punuk unta).
\end{abstract}

Kata Kunci: Dakwah, film 99 Cahaya di langit Eropa

\title{
Pendahuluan
}

Dakwah adalah adalah setiap usaha atau aktivitas dengan lisan, tulisan dan lainnya yang bersifat menyeru, memanggil manusia untuk beriman dan menaati Allah sesuai dengan garis-garis akidah dan syariat 
Nasruddin \& Ach Zulfikar Ali: Pesan Dakwah dalam Film | 95-122 serta akhlak Islamiyah. ${ }^{1}$

Sesuai dengan yang difirmankan oleh Allah dalam surah Āli 'Imrān ayat 104 yang artinya Dan hendaklah ada di antara kamu segolongan umat yang menyeru kepada kebajikan, menyuruh kepada yang ma'ruf dan mencegah dari yang munkar; merekalah orang-orang yang beruntung. (QS Ali 'Imrān:104)²

Dari ayat ini dapat ditangkap secara jelas bahwa tugas berdakwah merupakan pekerjaan yang sangat mulia untuk menyelamatkan orangorang dari perbuatan munkar.

Untuk berdakwah itu bisa dengan media apa saja, dan Media dakwah yang pada awalnya lebih banyak menggunakan media tradisional, berkembang menjadi lebih banyak variasinya dengan menggunakan sentuhan-sentuhan teknologi media massa modern; baik dengan media cetak yang variatif (buku, koran, majalah, tabloid, dan lain-lain) maupun dengan media elektronik yang variatif pula (radio, televisi, film, VCD, internet dan lain sebagainya).

Di antara beberapa hasil dari perkembangan teknologi yang paling besar adalah berkembangnya media audio visual, termasuk film salah satunya. Film terus mengalami perkembangan yang sangat signifikan hingga saat ini dan peminatnya juga sangat banyak. ${ }^{3}$ Sehinga tidak lagi dijadikan media hiburan semata namun bisa dijadikan media komunikasi dalam dakwah dan pendidikan.

Oleh karenanya, Penyesuian dengan kondisi kekinian memang sudah seharusnya dilakukan, karena kesibukan dan mobilitas yang tinggi serta perubahan dan pergeseran sosial dan budaya yang tidak memungkinkan dakwah konvensional (seperti tabligh dan khițābah) mampu menjangkau masyarakat secara efektif. Maka dakwah dengan multimedia dan media massa terbaru akan sangat memungkinkan dijadikan alternatif di tengah kondisi dan tatanan kehidupan seperti sekarang4

\footnotetext{
${ }^{1}$ Moh. Ali Aziz, Ilmu Dakwah, Cet. 4 (Jakarta:Prenamadia Group, 2015), h. 11.

2 Kementerian Agama Republik Indonesia, Qur'an Hafalan, (Jakarta: Halim, 2013), h. 63 .

3 Nuruddin, Pengantar Komunikasi Massa, (Jakarta:PT Rajagrafindo Persada,2014), h. 59 .

4 Khafidhoh, Analisis Film Dalam Mihrob Cinta menurut Perspektif Dakwah Islam (Skripsi IAIN Walisongo, 2012).
} 
96-122 | Nasruddin \& Ach Zulfikar Ali

Dakwah melalui film, menurut para ahli juga dinilai efektif. Sebagaimana yang dikatakan Ali Aziz ${ }^{5}$, bahwa efektivitas media auditif seperti radio lebih rendah jika dibandingkan audio visual seperti film. Dan menurutnya, film memiliki kelebihan yang tidak dimiliki oleh media lain, seperti misalnya pers bersifat visual saja, radio bersifat auditif, maka film justru mencakup semuanya (audio visual). Sehingga tidak hanya cocok digunakan dalam media pendidikan saja.

Kelebihan lain dari media film sebagai media dakwah adalah da'i dalam menyampaikan pesan dakwahnya dapat diperankan seorang tokoh pemain dalam produksi film, tanpa harus ceramah dan berkhutbah seperti halnya pada majlis taklim. Sehingga secara tidak langsung para penonton merasa tidak merasa diceramahi atau digurui. Selain itu pesan dakwah dalam film lebih mudah disampaikan pada masyarakat, karena pesan verbal diimbangi dengan pesan visual yang memiliki efek yang sangat kuat terhadap sikap dan perilaku mad'u. Hal ini terjadi karena dalam film selain pikiran, perasaan pemirsa pun dilibatkan.

Di antara salah satu film yang banyak mengandung pesan dakwah itu adalah film 99 Cahaya di Langit Eropa. Film 99 Cahaya di Langit Eropa sendiri merupakan film drama religi rilis tahun 2013 yang ditulis oleh Guntur Soeharjanto yang mengadopsi kisah dari novel dengan judul yang sama karya Hanum Salsabila Rais dan Rangga Almahendrea yang mengisahkan bagaimana mereka beradaptasi di negara Eropa yang yang berbeda agama, ras, etnis, dan budaya.

Penelitian ini bertujuan [1] untuk Untuk memahami apa saja pesan dakwah dalam film 99 cahaya di langit Eropa.[2] Untuk mengetahui bagaimana makna denotatif, konotatif, dan mitos dalam film 99 cahaya di langit Eropa disampaikan dalam perspektif semiotika Roland Barthes

5 Moh. Ali Aziz, Ilmu..., h. 426. 
Nasruddin \& Ach Zulfikar Ali: Pesan Dakwah dalam Film | 97-122

\section{Pembahasan}

\section{A. Pesan Dakwah (berdasarkan tema pokok dakwah: aqidah, syariat dan akhlak)}

\section{Pesan dakwah yang terkait dengan akidah}

Scene 1- menjelaskan tentang kewajiban berpegang teguh kepada agama dan larangan makan babi

Pada signifikasi tahap pertama (denotatif), scene ini memvisualisasikan adegan antara Stefan yang tidak beragama (atheis) dan Rangga seorang muslim yang taat, tetap bisa bersahabat dengan baik meski mereka berdua berbeda agama. Stefan mencoba mengutarakan keheranannya kepada Rangga terkait daging babi, hingga akhirnya Rangga ditawarkan untuk makan daging babi oleh Stefan. Namun Rangga dengan tegas menolak permintaan Stefan karena ia sangat mencintai tuhannya (Allah SWT) dan tidak akan melangggar aturan-Nya, walaupunpun Stefan sudah menjelaskan kepada Rangga bahwa daging babi lebih enak dan murah.

Pada scene ini juga dimaknai secara konotatif bahwa Rangga benarbenar menjaga keimanannya dengan tidak memakan makanan yang diharamkan oleh Allah dalam al-Qur'an. Scene ini memuat pesan tauhid dan berkaitan dengan persoalan keimanan, dapat dilihat bagaimana visualisasi terhadap tokoh Rangga meninggalkan larangan Allah dalam al-Qur'an, (memakan daging babi). Setiap larangan dalam ajaran agama Islam mengandung hikmah. Boleh dikatakan bahwa scene ini ingin menyampaikan makna bahwa menghindari berbuat maksiat kepada Allah merupakan sikap orang mukmin. Allah berfirman dalam surat Al-Baqarah ayat 165 dan 285

Rasul telah beriman kepada Al Quranyang diturunkan kepadanya dari Tuhannya, demikian pula orang-orang yang beriman. Semuanya beriman kepada Allah, malaikat-malaikat-Nya, kitab-kitab-Nya dan rasul-rasul-Nya. (Mereka mengatakan): "Kami tidakmembeda-bedakan antara seseorangpun (dengan yang lain) dari rasul-rasul-Nya", dan mereka mengatakan: "Kami dengar dan kami taat". (Mereka berdoa): "Ampunilah kami ya Tuhan kami dan kepada Engkaulah tempat kembali". (QS Al-Baqarah: 285) 
98-122 | Nasruddin \& Ach Zulfikar Ali

Dan diantara manusia ada orang-orang yang menyembah tandingantandingan selain Allah; mereka mencintainya sebagaimana mereka mencintai Allah. Adapun orang-orang yang beriman amat sangat cintanya kepada Allah. Dan jika seandainya orang-orang yang berbuat zalim itu mengetahui ketika mereka melihat siksa (pada hari kiamat), bahwa kekuatan itu kepunyaan Allah semuanya, dan bahwa Allah amat berat siksaan-Nya (niscaya mereka menyesal). (QS Al-Baqarah, 165)

Pada konteks ini sutradara menggunakan metode berdakwah Hikmah (bi al-hikmah) yaitu menjelaskan rahasia dan faedah sesuatu. Karena memang larangan memakan babi sangat jelas dalam Al-Quran. Sebagaimana yang Allah firmankan dalam surat Al-Baqarah ayat 173:

Artinya:

Sesungguhnya Allah hanya mengharamkan bagimu bangkai, darah, daging babi, dan binatang yang (ketika disembelih) disebut (nama) selain Allah. Tetapi barangsiapa dalam keadaan terpaksa (memakannya) sedang dia tidak menginginkannya dan tidak (pula) melampaui batas, maka tidak ada dosa baginya. Sesungguhnya Allah Maha Pengampun lagi Maha Penyayang.(QS. Al-Baqarah: 173)

Untuk mengetahui hikmah dilarangnya makan daging babi, peneliti mengambil pendapat Hamka, beliau menjelaskan dalam tafsir Al-Azharnya, bahwa ada alasan di balik mengapa daging babi diharamkan dan tidak boleh konsumsi oleh orang muslim dan mu'min selain merupakan syari'at dari Al-Qur'an juga beberapa alasan karena di antara segala binatang, babilah yang paling kotor dan najis sehingga bekas dari makanan kotor itulah mempergemuk badannya, di dalam badan babi itu juga terdapat cacing pita yang terkenal. ${ }^{6}$

Pesan dakwah- Pembuat film ingin memberikan pemahaman para para penonton bahwa hidup di negara Eropa yang mayoritas beragama non muslim adalah tantangan yang tidak mudah. Hal tersebut dirasakan oleh Rangga selama tiga tahun belajar di Austria. Rangga selalu dihadapkan permasalahan makanan yang selalu bercampur dengan daging babi. Memerlukan keimanan yang kuat dan pemahaman Islam yang baik agar bisa bertahan hidup di negara Eropa sebagamana visualisasi kehidupan

${ }^{6}$ Hamka, Tafsir Al-Azhar Jilid 1, (Jakarta: Gema Insani, 2015), 316 
Nasruddin \& Ach Zulfikar Ali: Pesan Dakwah dalam Film | 99-122 dan pengalaman hidup Rangga dalam scene tersebut.

\section{Scene 2- Tentang kewajiban bertawakkal kepada Allah}

Pada scene, Stefan kembali mempertanyakan masalah ketuhanan (konteks akidah) yang dianut Rangga. Kali ini Stefan mempertanyakan tentang rukun Islam yang menurut Stefan dengan melakukan semua itu, tuhan yang dipercayai oleh Rangga telah membuat umat pengikutnya tersiksa.

Tidak hanya itu Rangga juga ditanyakan tentang keberadaan Tuhan yang dianutnya. Namun Rangga lebih memilih diam dan tidak menjawab tentang keberadaan Allah, kemudian Rangga dengan tegas memperkuatkan argumentasinya. Tahapan ini mempunyai makna denotatif bahwa scene ini menggambarkan sosok Rangga yang tetap berpegang teguh kepada tali (agama) Allah. Dan Rangga juga memiliki komitmen untuk tidak melanggar aturan agama. Meski ia hidup dinegara ketat terhadap kaum minoritas.

Pada scene ini, dimaknai dengan konotatif bahwa apa yang menjadi jawaban Rangga atas pertanyaan Stefan, sebagaimana yang tergambar dalam dialog adalah simbol kekuatan akidah dan prinsip seorang muslim sejati yang harus tertanam dalam hati.

Bisa dilihat dari beberapa pernyatan Rangga ditanya tentang eksistensi keimanannya, sebagaimana tercantu di dialog:

Sholat, puasa, dan ibadah haji itu termasuk premi asuransi saya ke Tuhan

Jika dirunut dari apa yang dikatakan Rangga, sangat sesuai dengan tuntunan dari ayat Al-Quran surah al-An‘ām ayat 162 yang artinya:

Katakanlah: sesungguhnya sembahyangku, ibadatku, hidupku dan matiku hanyalah untuk Allah, Tuhan semesta alam.

Penegasan rangga dalam akhir dialog misalnya, Aku tidak pernah merasa terbebani dengan apa yang saya lakukan, saya bahagia saya merasa tenang

Pernyataan penguat Rangga dalam dialog tersebut, memberikan arti bahwa Rangga memberikan penjelasan yang sangat terang tentang arti tawakkal. Rangga menyadari konteks keimanan ini. Tawakkal sendiri berarti menyakini bahwa Allah adalah sebaik-baiknya tempat bersandar. 
100-122 | Nasruddin \& Ach Zulfikar Ali

Tidak ada satupun selain Dia yang layak dijadikan tempat menyandarkan segala urusan, menyangkut segala aspek kehidupan manusia. ${ }^{7}$

Jadi, boleh dikatakan bahwa sikap optimisme hidup seorang hamba dalam tugas penghambaannya kepada Allah merupakan salah satu unsur penting menjalan perintah Allah dalam Al-Qur'an yang berupa sifat Tawakkal.

Tujuannya dari hidup penuh rasa tawakkal itu sendiri adalah menciptakan optimisme dalam jiwa bahwa zat yang sebaik-baiknya tempat menyandarkan segala urusan manusia dengan harapan (al-rajā') semua perbuatan yang direncanakan, sedang, dan akan diperbuat, tidaklah berguna dan sia-sia. ${ }^{8}$

Allah Berfirman dalam surah Āli 'Imrān ayat 159. Yang artinya:

Apabila kau telah bertekad, bertawakkallah kepada Allah (QS Āli 'Imrān:

159)

Wahbah Al-Zuhailī memaparkan bahwa dalam ayat ini kedudukan bertawakkal kepada Allah adalah hal sangat penting, dan merupakan salah satu manifestasi dari keimanan seseorang. ${ }^{9}$

Dalam scene tersebut ada hal yang menarik ketika Stefan mempertanyakan dimana tuhan Rangga berkantor dengan kutipan dialog sebagai berikut:

Perusahaan asuransi yang setiap bulan yang aku bayar 80 Euro itu ada kantornya, dan aku tahu kantornya dimana! Tuhan kamu kantornya dimana? Kalau seandainya tuhan kamu benar-benar tidak ada gimana?

Cara menjawab ini yang dilakukan oleh Rangga tersebut sesuai dengan cara yang dilakukan Ibnu Kathīr dalam menafisrkan surat al-A'rāf ayat 54 dan surat Ṭāhā ayat 5 . Dalam menafsirkan ayat tersebut, Ibnu Kathīr berkata, dalam hal ini kami menempuh jalan para al-salaf al-ṣalih, yaitu Imam Mālik, al-Auzā'ī, al-Thauri, al-Laits bin Sa'd, al-Shāfi'ì, Aḥmad, Ish>āq bin Rahawiyah, dan imam-imam lainnya, yakni membiarkan seperti apa adanya, tanpa takyïf (mempersoalkan kaifiatnya/hakikatnya), Tashbih

\footnotetext{
7 Rif'at Syauqi Nawawi, Kpribadian Qur'ani, (Jakarta: Amzah, 2014), h. 79.

${ }^{8}$ Ibid

${ }^{9}$ Ibid
} 
Nasruddin \& Ach Zulfikar Ali: Pesan Dakwah dalam Film | 101-122 (penyerupaan), ta'țil (penolakan).

Adapun al-Sayyid Muhammad 'Alawī al-Mālikī al-Ḥasanī dalam memberikan pandangan tentang pertanyaan Allah di mana? Beliau mengatakan: Mayoritas ulama Ahlus Sunnah tidak mengatakan dengan makna arah yang dikenal manusia secara fisik atau makna tempat. Karena arah dan tempat adalah sifat-sifat yang dimiliki makhluk-Nya. ${ }^{10}$

Dalam konteks analisis ini, sutradara ingin menyampaikan pesan dakwah bawa jika ada orang yang menanyakan keberadaan Allah, maka dalam hal ini, pertanyaan tersebut digolongkan dengan masalah akidah.

Pesan dakwah-dalam dialog dan potongan scene tersebut di atas sangat sesuai dengan ajaran agama Islam. Ide yang ingin diambil oleh sutradara memaknai pesan dakwah melalui adegan yang diperankan oleh Rangga tersebut mencerminkan bahwa, hidup di negara Austria, yang merupakan lingkungan mayoritas orang-orang kafir (non muslim), bukanlah sebuah halangan untuk tidak menjaga keimanan, meskipun terkadang harus berbenturan dengan budaya, agama, dan prinsip.

\section{Scene-3 Tentang Peranan Hidayah Allah dalam kesuksesan dakwah}

Scene ini memvisualisasikan adegan Hanum dan Rangga menziarahi makam Ayse. Ayse merupakan gadis cilik yang banyak menginspirasi hidup Hanum, terutama ketika Hanum sudah mendapatkan hidayah tentang arti penting berhijab bagi seorang muslimah. Namun sayang janji Hanum untuk segera mengenakan hijab pupus begitu saja, karena Ayse sudah meninggal dunia setelah berjuang melawan kanker yang ia derita. Namun akhirnya Hanum telah menemukan hidayah dan memutuskan untuk berhijab dengan ikhlas setelah mendapat inspirasi dari Aesya

Pada scene ini, jika dimakani secara konotatif maka Hanum benarbenar telah mendapatkan hidayah Allah tentang berhijab. Keputusan tersebut sangat bulat dan kuat. Dalam menemukan hidayah tersebut ada sosok yang menginspirasinya yaitu Ayse.

Dalam Islam masalah hidayah atau petunjuk hanyalah milik Allah, bagaimanapun upaya seseorang, bagaimanapun kerja kerasnya untuk

${ }^{10}$ Al-Sayyid Muḥammad 'Alawī al-Mālikī al-Ḥasanī, Huwa Allāh (Mekkah: Hai'ah al-Ṣafwah al-Mālikiyah, tanpa tahun), 48-49. 
102-122 | Nasruddin \& Ach Zulfikar Ali

menyadarkan seseorang, maka itu tidak ada artinya jika Allah tidak menghendaki hidayah kepadanya." Allah berfirman dalam Al-Quran,

Sesungguhnya kamu tidak akan dapat memberi petunjuk kepada orang yang kamu kasihi, tetapi Alloh memberi petunjuk kepada orang yang dikehendaki-Nya, dan Alloh lebih mengetahui orang-orang yang mau menerima petunjuk. (QS al-Qașaṣ:56)

Proses hijrahnya Hanum menjadi muslimah yang seutuhnya merupakan proses yang panjang, tidak serta-merta Hanum langsung berkomitmen untuk berhijab. Namun hidayah Allah telah datang menjemputnya. Keteladanan yang diberikan Ayse kepada Hanum kini sudah membuahkan hasil. Akhirnya ia benar-benar termotivasi dan berhijrah ke jalan Allah. Berpegang teguh dengan ajaran Agama Islam.

Hanum menyakini atau mengimani sepenuhnya bahwa yang memberikan benar-benar Allah untuk mengikuti perintah bejilbab yang tercantum dalam surat Al-Nūr ayat 31. Ayse adalah hanyalah perantara untuk mendapatkan pesan-pesan dakwah Islam. Dakwah bil hal Ayse kepada Hanum telah mengantarkan Hanum menemukan jati dirinya sebagai muslimah sejati.

Dalam penjelasan Asbāb al-Nuzūl dari surat al-Qașaṣ ayat $5^{6}$ tersebut di atas, Turunnya ayat ini berkenaan dengan cintanya Rasulullah SAW kepada pamannya, Abu Ṭālib. Akan tetapi, segala cara dan upaya yang dilakukan beliau untuk mengajak pamannya kepada kebenaran, tidak sampai membuat pamannya menggenggam Islam sampai ajal menjemputnya. Seorang rasul yang kita tahu kedudukannya di sisi Allah saja tidak mampu untuk memberi hidayah kepada pamannya, apalagi kita yang keimanannya sangat jauh dibandingkan beliau. ${ }^{12}$

Terdapat dua pengertian hidayah jika merujuk dari beberapa tafsirtafisr pada ulama. Pertama, hidayah sebagai petunjuk informatif, yaitu memberikan pemahaman tentang pesan Islam. Kedua, hidayah sebagai petunjuk pembinaan. Dalam hal ini, masyarakat dibimbing dan digerakkan

${ }^{11}$ Rian permana, https://muslim.or.id/5401-hidayah-milik-allah.html diakses tangggal o4 April 2017 Jam 21:31

${ }^{12}$ Ibid 
Nasruddin \& Ach Zulfikar Ali: Pesan Dakwah dalam Film | 103-122 untuk menjalankan ajaran Islam. ${ }^{13}$

Pesan dakwah, mengenai konteks hidayah dalam Islam, kita dapat memahami makna kebebasan dalam dakwah. Pendakwah bukan penentu akhir akan tetapi hanya bersifat pendorong saja. Yang berhak untuk memberikan hidayah adalah Allah SWT saja selain Dia tidak ada yang bisa memberi petunjuk.

Apa yang dilakukan Ayse adalah sangat representatif dengan pernyataan-pernyataan di atas. Ayse benar-benar tidak bisa mengajak Hanum secara langsung memakai hijab karena memberikan hidayah bukanlah tugasnya.

\section{Pesan dakwah yang terkait dengan syari'ah}

Scene4- tentang kewajiban memakai jilbab bagi seorang muslimah dan mengajarkan anak perempuan berjilbab

Scene ini memvisualisasikan bahwa Aesya adalah satu-satunya anak yang yang berjilbab di kelasnya. Memakai jilbab di negara Austria adalah hal yang tabu, sehingga tidak berlebihan jika Ayse selalu mendapatkan kekerasan verbal dari teman-temannya. Guru Ayse pun sangat menyayangkan hal itu terjadi dan kemudian meminta Ayse untuk melepas jilbabnya ketika di sekolah, dengan alasan agar Ayse mendapatkan ketenangan dan tidak lagi diolok teman-temannya, namun Aysa dengan penuh pendirian menolak usulan gurunya.

Kemudian Fatma (ibu Aysa) menegaskan kembali kepada gurunya bahwa Ayse sangat bahagia dengan sabar atas pilihanya menjadi gadis muslimah yang berjilbab. Maka, pada scene bisa dimaknai secara denotatif bahwa Ayse tidak pernah menyesal dengan apa yang menjadi pilihannya apalagi dia mempunyai seorang ibu yang selalu mendukung atas apa yang telah menjadi pilihannya sendiri.

Scene ini mempunyai makna konotatif, bahwa berjilbab adalah simbol kehormatan yang dikhususkan Islam kepada perempuan serta mengajarkan anak perempuan dari sejak dini tentang jilbab (menutup aurat) adalah hal yang wajib bagi orang tua. Ada banyak dalil yang

${ }_{13}$ Ali Aziz, Ilmu....., h. 123 
104-122 | Nasruddin \& Ach Zulfikar Ali

menegaskan wajibnya memakai jilbab bagi wanita muslimah. Sekaligus hal ini menjadi pesan dakwah utama dalam scene ini.

Allah berfirman dalam Al-Quran,

Katakanlah kepada wanita yang beriman: "Hendaklah mereka menahan pandangannya, dan kemaluannya, dan janganlah mereka menampakkan perhiasannya, kecuali yang (biasa) nampak dari padanya. Dan hendaklah mereka menutupkan kain kudung kedadanya....(QS al-Nür: 31$)$

Berjilbab $^{14}$ adalah ciri-ciri mukminah sejati. Dengan arti bahwa seorang Aysa tidak akan melepaska jilbabnya hanya karena ia sering diperolok-olok oleh teman-teman sekelasnya. Bahkan ia dengan senang hati melaksanakan kewajibannya. Hingga gurunya pun menganjurkan untuk melepaskan saja jilbabnya.

Permintaan guru Ayse ini memberikan gambaran bahwa kebebasan menjalankan ajaran agama di negara Austria, khususnya di sekolah-sekolah kerap mengalami intimidasi bahkan mengarah pada sikap rasis. ${ }^{15}$ Namun meski demikian, Ayse tetap patuh ajaran Agama dan tidak bergeming sedikitpun.

Dalam menentukan pilihannya, Ayse tentunya mendapatkan dorongan kuat dari ibunya (Fatma) sebagaimana terlihat padascenescenesebelumnya. Ibunyalah sumber keteladanan utama Ayse untuk kuat dalam menjalankan perintah agama (syari'at) tersebut. Sehingga Ayse tidak sekalipun merasa terpaksa dan terbebani dengan pilihannya. Semua itu tervisualisasikan pada jawaban Fatma ketika dia bertemu dengan guru Ayse.

Scene ini tidak saja dibuat begitu melainkan ada dalil Al-Quran yang harus ingin disampaikan sampaikan, yaitu

Hai Nabi, katakanlah kepada istri-istrimu, anak-anak perempuanmu, dan istri-istri orang Mukmin: Hendaklah mereka mengulurkan jilbabnya ke

${ }^{14}$ Ali As-Shabuni menafsirkan maksud berjilbab/berkerudung yaitu menutup kepala hingga ke dada, agar tidak ada bagian leher dan dada yang tampak (Ali-As-Shabuni, Shafwatut Tafasir (Tafsir-tafsir Pilihan) jilid 3, Cet. 1 (Jakarta Timur: Pustka Al-Kautsar, 2001), h.)

${ }^{15}$ Menurut berita yang dimuat www.eramuslim.com pada tanggal 7 Januari 2017 negara Austria telah menyiapkan undang-undang larangan berjilbab lingkungan PNS dan Sekolah. 
Nasruddin \& Ach Zulfikar Ali: Pesan Dakwah dalam Film | 105-122 seluruh tubuh mereka. (QS al-Aḥzāb: 59).

Pesan dakwah, dalam scene ini lebih ditekankan kepada ajakan berjilbab untuk kaum muslimat sekaligus menggambarkan pentingnya melatih anak perempuan untuk mengenakan jilbab semenjak mereka masih belia. Karena mendidik anak untuk berjilbab sama wajibnya mendidik anak untuk puasa dan shalat. Dan secara hakekatnya, kesemua itu ada perintahnya dalam ajaran Islam dan sama-sama wajib dilaksanakan.

Namun dalam membimbing anak perempuan berjilbab membutuhkan dukungan dan keteladanan orang tua secara langsung. Agar anak lebih percaya diri dalam menjalankan kewajiban yang sedang mereka jalani sebagai muslimah sejati.

\section{Pesan dakwah yang terkait dengan akhlak}

Scene 5 - Scene tentang kewajiban membalas kejahatan dengan kebaikan

Scene ini menggambarkan suasana Fatma yang sedang menenangkan sikap Hanum yang terpancing emosi ketika mendengar percakapan dua orang di luar kafe. Hanum sangat kesal karena apa yang diucapkan kedua pemuda yang sedang berbicara santai. Karena percakapan tersebut mengandung unsur pelecahan terhadap negara sahabatnya, Fatma. Namun Hanum kaget karena Fatma sama sekali tidak terpancing emosi. Justru Fatma memilih cara lain untuk menghadapi pelecehan yang dilakukan kedua pemuda tersebut. Yaitu dengan mentraktir Cruissant tanpa sepengetahuan mereka terlebih dahulu.

Pada scene ini dapat dimaknai secara denotatif bahwa Fatma menampakkan kelasnya kepada Hanum dalam hal kebijaksanaan mengambil sikap tidak beratanggung jawab seperti yang dilakukan dua pemuda di kafe tersebut dan juga tampak Fatma lebih mengedapankan kedewasaan berfikirnya. dengan penuh keyakinan dan tanpa berfikir panjang, Fatma dengan cerdik meredam masalah tersebut dengan membalas kejahatan yang mereka lakukan dengan berbuat kebaikan yang jauh lebih bermartabat.

Pada scene ini mempunyai makna konotatif, bahwa apa yang dilakukan oleh Fatma dalam scene tersebut merupakan simbolisasi kuatnya 
106-122 | Nasruddin \& Ach Zulfikar Ali

pemahaman Fatma terhadap karakter orang non muslim yang tidak mengerti tentang Islam. Fatma tahu cara menghadapi dua pemuda non muslim yang berbuat kejahatan kepadanya dengan lebih mengedapankan cara-cara yang diajarkan Islam. Yaitu, membalaskan kejahatan tidak mesti dengan kejahatan pula, namun dengan kebaikan. Hal itu semua langsung diajarkan dalam Al-Quran.

Allah Berfirman dalam surah al-A'rāf ayat 199:

Jadilah engkau pemaaf dan suruhlah orang mengerjakan yang ma'ruf, serta berpalinglah dari pada orang-orang yang bodoh. (QS al-A'rāf: 199)

Mengenai ayat ini, M. Quraish Shihab dalam Tafsir Al-Mishbah, beliau menafsirkan bahwa perintah memberi maaf kepada Nabi Muhammad SAW tidak berkaitan dengan ketentuan agama. Perintah tersebut adalah yang berkaitan dengan kesalahan dan perlakuan buruk terhadap peribadi beliau. ${ }^{16}$

Jadi, ayat ini menggambarkan kemulian hati Rasulullah dalam menegakkan agama Allah dimuka bumi dan sekaligus menjadi pedoman bagi agen dakwah yang harus diamalkan. Jadi boleh dikatakan, apa yang dilakukan Fatma memilih cara tidak membalas kejahatan dengan kejahatan adalah merupakan perbuatan yang memang seharusnya demikian. Dan semua itu ada panduannya dalam Islam.

Sebagaimana yang dikatakan oleh Hamka dalam Tafsir Al-Azhar tentang tafsiran ayat ini, beliau mengatakan ayat ini merupakan pedoman perjuangan yang diperingatkan Allah kepada Rasul-Nya. Tiga unsur wajib yang diperhatikan dan dipegang teguh di dalam menghadapi pekerjaan besar menegakkan dakwah kepada umat manusia. ${ }^{17}$

Nabi Muhammad SAW berpesan kepada Umatnya untuk menggunakan cara-cara yanglembut, tidak marah dan fanatik, sebagaimana dijelaskan dalam hadits riwayat Bukhārī dan Muslim dari Abu Hurairoh r.a bahwa Rasulullah bersabda, "Orang yang kekar bukanlah yang pandai berkelahi, melainkan yang mampu mengendalikan diri ketika marah”.

Dalam surah Āli 'Imrān ayat 159, Allah menggambarkan rahasia

${ }^{16}$ M. Quraish Shihab, Tafsir Al-Misbah; Pesan, Kesan, dan Keserasian Al-Quran Volume 4,Cet. V(Jakarta: Lentera Hati, 2012), h. 428.

${ }_{17}$ Hamka, Tafsir Al-AzharJuz 7, 8, dan 9, (Jakarta: Pustaka Panjimas, 1983), h. 221. 
Nasruddin \& Ach Zulfikar Ali: Pesan Dakwah dalam Film | 107-122

sukses dakwah Rasulullah Saw. yang dianugerahi nikmat yang teragung dari Allah SWT yaitu nikmat senantiasa besikap lemah lembut, lapang dada, memaafkan terhadap perilaku kasar orang lain, ${ }^{18}$

Maka disebabkan rahmat dari Allah-lah kamu berlaku lemah lembut terhadap mereka. Sekiranya kamu bersikap keras lagi berhati kasar, tentulah mereka menjauhkan diri dari sekelilingmu. Karena itu maafkanlah mereka, mohonkanlah ampun bagi mereka, dan bermusyawaratlah dengan mereka dalam urusan itu. Kemudian apabila kamu telah membulatkan tekad, maka bertawakkallah kepada Allah. Sesungguhnya Allah menyukai orang-orang yang bertawakkal kepada-Nya. (QS Āli 'Imrān, 159)

Dan pada akhir dialog tersebut Fatma menegaskan bahwa Islam bukan agama teroris dan pemeluknya tidak dibenarkan melakukan hal-hal yang mengarah kepada terorisme. Karena memang misi Islam adalah misi luhur yang serius melakukan perbaikan maka prinsip yang dipegang adalah menjauhi kebodohan dan berpaling dari perbuatan keji, agar iringaniringan dakwah tetap melaju menuju tujuan yang mulia, yaitu tersiarnya Islam.

...Tolaklah perbuatan buruk mereka dengan yang lebih baik. Kami lebih mengetahui apa yang mereka sifatkan. (QS al-Mu'minūn: 96).

Barangsiapa yang datang dengan (membawa) kebaikan, maka baginya (pahala) yang lebih baik daripada kebaikannya itu; dan barangsiapa yang datang dengan (membawa) kejahatan, maka tidaklah diberi pembalasan kepada orang-orang yang telah mengerjakan kejahatan itu, melainkan (seimbang) dengan apa yang dahulu mereka kerjakan. (QS al-Qașaș:84)

Pesan dakwah yang yang ingin disampaikan oleh pencerita film dalam scene ini adalah tentang pentingnya membalas kejahatan dengan kebaikan. Membalas kejahatan tidak mesti dengan kejahatan pula. Ada tuntunan khusus dalam Islam bagaimana seharusnya menangani orang yang berbuat jahat kepada kita. Karena secara hakekatnya, Islam adalah agama yang mengajarkan kelembutan dan melarang bersikap kasar.

Apabila kita melihat dari segi sosio-kultural di masyarakat yang ada, terkadang konflik sosial yang sering terjadi, sering disebabkan masalah

${ }^{18}$ Atabik Luthfi, Tafsir Tazkiyah; Tadabbur Ayat-ayatuntukpencerahan \& penyucian hati, Cet. 1 (Depok: Gema Insani, 2009), h. 41. 
108-122 | Nasruddin \& Ach Zulfikar Ali

sepele, misalnya salah paham, mudah tersinggung, dendam kesumat dan lain-lain. Itu menandakan belum sempurnanya pengamalan dan penghayatan makna Islam sesungguhnya.

Menurut penulis, adegan yang diperankan Fatma dan Hanum sebagaimana dibahas di atas representatif dengan pesan dakwah yang bersumber dari ayat yang telah disebutkan. Dan juga, sangat repsentatif dengan sikap Rasulullah ketika menghadapi orang-orang kafir yang menghina dirinya. Rasulullah lebih memilih bersabar, memaafkan, dan membalas keburukan mereka lakukan dengan kebaikan. Bahkan dengan cara seperti itulah Rasulullah berhasil mengIslamkan orang Mekkah dan Madinah.

\section{Scene 6- pesan dakwah tentang selalu berbuat baik kepada orang lain, memaafkan kesalahan orang lain.}

Terlihat pada scene ini, Hanum memberikan kejutan kepada Alex yang merupakan tetangga satu apartemennya. Hal tersebut memang sudah direncakan Hanum bersama suaminya Rangga untuk menghibur Alex yang pada hari-hari sebelumnya sempat menghardik Hanum sedang memasak, karena menurut Alex masakan Hanum mengeluarkan bau tidak sedap dan menyengat. Scene ini dimaknai secara denotatif apa yang dilakukan oleh Hanum bersama suami merupakan salah satu bukti kreatifnya mereka berdua membalas kekasaran sikap Alex kepadanya. Karena memang Islam melarang membalas kejahatan dengan kejahatan.

Scene ini memvisualisasikan makna tersirat yang berupa pentingnya berbagi serta menjalin hubungan baik dengan tetangga. Dalam dialog yang terdapat pada scene ini tampak jelas kedewasaan sikap Hanum dalam meresapi makna Islam sesungguhnya. Sebagaimana yang terdapat dialog pengiring.

Sekarang aku mulai memahami tentang makna Islam sebenarnya, karena dalam Islam itu bukan pedang tapi kedamaian, karena Islam itu kreatifitas bukan simbol-simbol

Ketika hanum mengatakan bahwa Islam bukan agama pedang, terdapat makna denotasi bahwa kata pedang memang identik dengan 
Nasruddin \& Ach Zulfikar Ali: Pesan Dakwah dalam Film | 109-122 benda tajam, dapat melukai, dan menakutkan. Namun jika diartikan secara konotasi, makna yang yang diinginkan dari kata tersebut merupakan simbol optimisme Hanum dalam mengarungi hidup di negara Eropa, Hanum menyakini sepenuhnya, agama yang ia peluk adalah agama yang yang menjunjung tinggi toleransi dan kerukunan umat beragama. Islam tidak memperkenalkan terorisme dan melarang bertindak kasar ke sesama manusia.

Kata ini merupakan sangat repsentatif dengan apa yang menjadi dakwah Nabi Muhammadpada awal-awal menyebarkan Islam. Nabi Muhammad menolak memakai kekerasan dalam menaklukkan hati orang Arab yang terkenal sangat keras. Tapi sebaliknya lebih menggunakan caracara humanis dan dengan cara raḥmatan li al-ālamīn. Sehingga dengan cara itulah nabi Muhammad semakin dicintai, Islam semakin diterima dan mampu menaklukkan kerasnya orang Arab yang menolak ajaran Islam tanpa menggunakan pedang yang merupakan salah satu simbol tindak kekerasan. Barangkali itulah yang ingin Hanum sampaikan dalam scene tersebut.

Allah sudah menggambarkan dalam Al-Quran surah al-Naḥl ayat 125, bagaimana seharusnya Islam itu disampaikan

Serulah (manusia) kepada jalan Tuhanmu dengan hikmah dan pelajaran yang baik dan bantahlah mereka dengan cara yang baik. Sesungguhnya Tuhanmu Dialah yang lebih mengetahui tentang siapa yang tersesat dari jalan-Nya dan Dialah yang lebih mengetahui orang-orang yang mendapat petunjuk. (QS al-Nahl: 125)

Secara gamblang, perkataanHanum, "Islam itu kreatifitas bukan simbol-simbol", mengandung makna bahwa Islam adalah sumber jawaban dan solusi dalam setiap derap langkah kaki Hanum bersama suaminya selama kurang lebih 3 tahun hidup di Eropa. Islam menuntut pemeluknya untuk selalu kreatif dalam menyebarkan ajaran agama Islam. Selama itu dalam koridor yang dibenarkan oleh syari'at Islam itu sendiri.

Untuk menghadapi membalas perlakuan kasar Alex kepada Hanum, dia dan suaminya lebih menggunakan pendekatan kekeluargaan yaitu memberikannya kejutan. Karena bagaimanapun ia adalah tetangga 
110-122 | Nasruddin \& Ach Zulfikar Ali

satu apartemen mereka. Meski sebenarnya, Alexbersikap kasar dengan mengeluarkan kata yang tidak pantas dan intoleransi.

Dari Abu Hurairah r.a bahwa Rasululllah bersabda:19

Barang siapa yang beriman kepada Allah dan hari akhir hendaknya jangan menyakiti tetangganya (HR Bukhari Muslim)

Namun sebagai muslimah, Hanum tidak diperbolehkan membalas kejahatan dengan kejahatan. Allah berfirman:

Tidak ada kebaikan pada kebanyakan bisikan-bisikan mereka, kecuali bisikan-bisikan dari orang yang menyuruh (manusia) memberi sedekah, atau berbuat ma'ruf, atau mengadakan perdamaian di antara manusia. Dan barangsiapa yang berbuat demikian karena mencari keridhaan Allah, maka kelak Kami memberi kepadanya pahala yang besar. (QS al-Nisā': 114)

Bila kita amati ayat ini dengan seksama, maka kita temukan bahwa pertama-tama Allah memerintahkan manusia untuk beribadah hanya kepada-Nya, kemudian Dia memerintahkan manusia untuk berbuat baik kepada sesama. Sehingga beradasarkan ayat Al-Quran ini, maka berbuat baik kepada tetangga merupakan hal yang sangat penting. ${ }^{20}$

Berbuat baik dan memuliakan tetangga merupakan perintah agama Islam yang sangat penting, bahkan Islam menaruh perhatian besar terhadap hubungan antar-tetangga. Oleh karenanya potongan Scene ini ingin menyampaikan ajaran agama yang terdapat di dalam Al-Quran diatas. Karena berbuat baik dengan tetangga tidak mesti dengan sesama orang Islam saja namun juga berlaku bagi penganut agama lain.

Bahkan dalam adegan ini sebenarnya representasi dari hadits Nabi, Wahai Abu Dzar, apabila kamu memasak sayur (daging kuah) maka perbanyaklah airnya dan berilah tetanggamu (HR Muslim). ${ }^{21}$

Inisiatif Hanum memberikan makanan siang kepada tetangganya tersebut digolongkan perbuatan ma'rūf karena ada dalil dalam hadits Nabi yang

${ }^{19}$ Thaha Abdullah 'Afifi, 120 Kunci Surga dari Qur'an \& Sunnah, Cet. 10 (Jakarta: Gema Insani 1994). H. 178

${ }^{20}$ Abdul Mun'im Al-Hasyimi, Akhlak Rasul Menurut Bukhari\&Muslim, Cet. 4 (Jakarta; Gema Insani, 2013), h. 73 .

${ }^{21}$ Muhammad Fuad Abdul Baqi, Shohih Muslim Jilid 4 ,Cet. 1 ( Jakarta: Pustaka AsSunnah, 2010), h. 451 
Nasruddin \& Ach Zulfikar Ali: Pesan Dakwah dalam Film | 111-122 menerangkan tentang itu.

Pesan dakwah yang terdapat di dalam scene ini lebih dominan kepada penyampaian pesan tentang kewajiban berbuat baik kepada tetangga. Kita tahu bahwa berbuat baik kepada tetangga merupakan perintah Rasulullah secara khusus. Sangat banyak hadits beliau yang menerangkan keutamaan berbuat baik kepada tetangga tersebut bahkan beliau menyatakan sebagai salah satu orang-orang beriman. Beliau bersabda,

Dan barang siapa yang beriman kepada Allah dan hari akhir hendaknya memuliakan tetangganya. (HR Muslim)

Berbuat baik kepada tetangga sebagaimana yang disebut di atas tidak hanya terbatas hubungan antara muslim dengan muslim saja, akan tetapi kepada non muslim juga. Karena perintah dalam hadits tersebut bersifat umum.

Oleh karenanya, apa yang divisualisasikan oleh sutradara dalam adegan ini sebenarnya memberikan pemahaman kepada para penonton dan masyarakat Islam pada umumnya bahwa berbuat baik kepada orang yang berbeda agamapun merupakan kewajiban. Karena Islam adalah agama rậmatan li al-'álamìn

\section{Scene 7- pesan dakwah tentang Sedekah}

Adegan ini menggambarkan ide kreatif atau sebuah terobosan yang dilakukan seorang pengusaha kuliner Muslim dengan menjadikan restorannya sebagai ladang amal dengan konsep ikhlas dan sedekah. Mr. Deewan sangat memahami kultur budaya orang Austria yang lebih mengedepankan nilai kejujuran. Bahkan Deewan berani menuliskan Makan Sepuasnya dan bayar sesukanya. Kata ini dimaknai denotatif bahwa Deewan sebenarnya menginginkan restoran miliknya tidak hanya dijadikan tempat makan semata atau tidak hanya dijadikan tempat mengambil keuntungan (omzet) semata. Melainkan tempat berbagi bagi sesama muslim dan non muslim secara umum.

Jika dimaknai secara konotatif, pada scene ini mengandung arti bahwa apa yang di lakukan Deewan merupakan simbolisasi sifat kedermawanan harus ada dalam diri seorang muslim sejati. Dan apa yang 
112-122 | Nasruddin \& Ach Zulfikar Ali

dilakukan Deewan ini juga merupakan terobosan inovatif yang bagus dalam memperkenalkan Islam kepada orang non muslim di Eropa. Bahwa Islam adalah agama yang ramah, toleran, menjunjung tinggi nilai-nilai kejujuran dalam mu'àmalah.

Islam tentunya sangat membenci sifat kikir, pelit dan rakus terhadap harta benda. Dalam konteks ini, Deewan menyadari betul, berbisnis sambil beramal adalah salah satu hal penting dilakukan di benua Eropa. Setidaknya Deewan mampu memperkenalkan Islam dengan caranya sendiri. Tentunya ia sendiri yang menjadi agen dakwahnya.

Pada scen di atas, Deewan sengaja menulis, "Makan sepuasnya dan bayar sesukanya" di dinding restoran miliknya. Jika ditinjau dari segi semiosis maka kata tersebut mengandung arti pesan dakwah, bahwa Deewan benar-benar ingin berbagi (bersedekah) baik kepada sesama muslim maupun non Muslim tanpa mengharapkan keuntungan yang besar dari hasil berbisnisnya. Karena keuntungan sebenarnya adalah sudah dijamin oleh Allah sebagai mana yang dijelaskan oleh Allah dalam Al-Quran:

Allah berfirman,

Perumpamaan (nafkah yang dikeluarkan oleh) orang-orang yang menafkahkan hartanya di jalan Allah adalah serupa dengan sebutir benih yang menumbuhkan tujuh bulir, pada tiap-tiap bulir seratus biji. Allah melipat gandakan (ganjaran) bagi siapa yang Dia kehendaki. Dan Allah Maha Luas (karunia-Nya) lagi Maha Mengetahui. (QS Al-Baqarah: 261)

Di dalam hadits Rasulullah juga bersabda,

Ttidak akan pernah berkurang harta yang disedekahkan, kecuali ia bertambah..bertambah..bertambah (HR al-Tirmidzī).

Dalam hadits lain.

Sungguh di sebagian malam ada satu saatyang tidak dihabiskan oleh seorang hamba Allah yang muslim dengan meminta kebaikan pada Allah berikan kebaikan itu kepadanya (HR Muslim). ${ }^{22}$

Alasan Deewan untuk mematok harga dengan sesuai kejujuran individu karena selain dijadikan ajang menambah amal ibadah, juga karena Allah tidak akan menyia-nyiakan amal ibadah seorang hamba. ${ }^{22}$ Ibid, h. xi-xii 
Nasruddin \& Ach Zulfikar Ali: Pesan Dakwah dalam Film | 113-122

Selain itu, untuk menunjang kesuksesan berbisnisnya, tentunya Deewan didukung kultur orang Eropa yang mendepankan kejujuran sebagaimana yang dikatakan Fatma pada potongan dialog: "Di Austria, semua berjalan berdasarkan kejujuran".

Dalam menjalani aktifitas bisnis tersebut, haruslah didasari dengan rasa tulus dan ikhlas, tidak meragukan kegunaan pemberian itu yang kembalinya tentu dengan imbalan yang besar dan pahala yang banyak. Karena pada hakikatnya sedekah itu adalah berarti menampakkan rasa syukur. ${ }^{23}$

Dan (ingatlahjuga), tatkala Tuhanmu memaklumkan; "Sesungguhnya jika kamu bersyukur, pasti Kami akan menambah (nikmat) kepadamu, dan jika kamu mengingkari (nikmat-Ku), maka sesungguhnya azab-Ku sangat pedih".(QS Ibrāhim: 7)

Selain itu, sebagai umat Islam tidak boleh menginfakkan sesuatu kecuali dengan niat hanya mencari keridhaan Allah Swt. Karena Allah mengembalikannyakepada kalian tanpasedikitpun. ${ }^{24}$

Pesan dakwah yang terdapat di dalam scene ini lebih dominan kepada penyampaian pesan tentang keutamaan sedekah. Kita dapat melihat tanda-tanda signifikasi yang diperankan tokoh Deewan dalam Film tersebut. Sutradara memvisualisasikan sedemikian rupa agar bahasa verbal dan non verbal dalam adegan itu dapat dipahami oleh para penonton. Dan pesan yang fenomenal menurut penulis adalah pesan verbal bisnis sambil beramal.

Bukanlah sebuah kebetulan sutradara menyampaikan pesan dakwah tersebut, namun hal tersebut sebenarnya merupakan representasi dan penjabaran pesan dakwah sesungguhnya yaitu surat Al-Baqarah: 267, hanya saja pesan tersebut disampaikan melalui audio visual (film). Allah berfirman,

Hai orang-orang yang beriman, nafkahkanlah (di jalan allah) sebagian dari hasil usahamu yang baik-baik dan sebagian dari apa yang Kami keluarkan dari bumi untuk kamu. Dan janganlah kamu memilih yang buruk-buruk

${ }^{23}$ Al-Sayyid Muḥammad 'Alawī al-Mālikī al-Ḥasanī, Al-Qudwah al-HasanahfF $>i$ Manhaj al-Da'wah, Terj. Samsul Munir Amin., Cet. 1 (Jakarta, 20o6), h. 43.

${ }^{24}$ WahbahAz-Zuhaili, EnsiklopediAKhlak h. 11. 
114-122 | Nasruddin \& Ach Zulfikar Ali

lalu kamu menafkahkan daripadanya, padahal kamu sendiri tidak mau mengambilnya melainkan dengan memincingkan mata terhadapnya. Dan ketahuilah, bahwa Allah Maha Kaya lagi Maha Terpuji.

Kenyataannya di lingkungan masyarakat, jargon berbisnis sambil beramal itu minim peminat. karena anggapan mereka tentunya hanya terbatas pada masalah mendapat keuntungan dan menghitung kerugian semata. Padahal dalam Islam tidak demikian. Justru dengan semakin banyak bersedekah maka harta itu semakin bertambah sebagaimana yang disebut dalam ayat dibawah ini.

Perumpamaan (nafkah yang dikeluarkan oleh) orang-orang yang menafkahkan hartanya di jalan Allah adalah serupa dengan sebutir benih yang menumbuhkan tujuh bulir, pada tiap-tiap bulir seratus biji. Allah melipat gandakan (ganjaran) bagi siapa yang Dia kehendaki. Dan Allah Maha Luas (karunia-Nya) lagi Maha Mengetahui. (QS. Al-Baqarah: 261)

\section{Pesan dakwah tentang sikap beragama}

\section{Scene 8- Menanggapi serangan non muslim terkait masalahan jilbab dan poligami}

Pada scene inimemvisualisasikan sosokStefan yangmempertanyakan perihal Hijab (Jilbab) dan Poligami kepada Rangga. Bagi stefan kedua hal itu merupakan bentuk ketidakadilan Islam terhadap kaum wanita. Perbincangan permasalahan agama sering terlihat pada scene sebelumsebelumnya. Dan kali ini yang terlihat pada akhir scene, Stefan puas mendengar analogi yang ditawarkan oleh Rangga kepadanya walaupun sebenarnya masalah hijab dan poligami adalah masalah sudah sangat jelas dalam syariat Islam.

Konotasi yang terlihat dalam adegan ini adalah usaha menjelaskan permasalahan fundamental dalam ajaran Islam, yang selama ini dipahami secara tidak objektif oleh Stefan. Ia Hanya melihat sisi luar saja tanpa melihatnya secara keseluruhan objek yang menjadi kritikannya. Sehingga yang terjadi adalah berburuk sangka terhadap isu-isu yang sebenarnya sudah tidak perlu terlalu serius mempermasalahkannya, Terkait permasalahan Jilbab memang bertujuan untuk menjaga kehormatan perempuan itu sendiri bukan untuk mengekang kebebasannya. Hal ini seperti dikatakan 
Nasruddin \& Ach Zulfikar Ali: Pesan Dakwah dalam Film | 115-122 dalam firman Allah SWT sebagai berikut:

Hai Nabi, katakanlah kepada istri-istrimu, anak-anak perempuanmu dan istri orang mukmin, hendaklah mereka mengulurkan jilbabnya ke seluruh tubuh mereka, yang demikian itu supaya mereka lebih mdudah untuk dikenal, karena itu mereka tidak diganggu. Dan Allah adalah Maha Pengampun lagi Maha penyayang. (QS. al-Aḩzāb:59)

Pada ayat lain, Allah berfirman mengenai bagaimana seharusnya perempuan berprilaku ditempat umum.

Hai istri-istri nabi, kamu sekalian tidaklah seperti perempuan yang lain, jika bertakwa.Janganlah kalian (kaum perempuan) berucap dengan nada lembut merayu sehingga menimbulkan gairah pada orang-orangyang berhati buruk untuk berbuat selingkuh. Dan ucaplah perkataan baik (QS al-Ahzāab:32)

Jelaslah, dari dua ayat diatas bukanlah hendak mengekang kebebasan berpakaian dan berprilaku bagi perempuan, justru Islam ingin menjaga kesucian dan melindungi kaum perempuan itu sendiri. ${ }^{25}$

Meskipun Islam mengharuskan perempuat menutup auratnya, Islam tidak mengharamkan perempuan untuk meniti karir, selama masih sejalan dan tidak melanggar fitrahnya selaku perempuan yang menjadi ibu bagi anak-anaknya. ${ }^{26}$

Kemudian terkait permaslahan poligami, pada hakikatnya poligami sudah ada sebelum Islam diturunkan bahkan sudah berurat akar pada hampir semua kebudayaan. Bahkan perempuan di zaman jahiliah seolah barang dagangan yang amat mudah dipindahtangankan. Namun sejak kedatangan Islam, harkat dan martabat perempuan ditinggikan, meski Islam tidak menghapuskan poligami, agama tauhid ini mengatur dan membatasinya secara ketat. Poligami ala Islam tidak menempatkan perempuan sebagai objek pemuas nafsu syahwat. Anak-anak hasil poligami pun tetap mendapatkan hak warisan setara hak anak anak istri tertua. ${ }^{27}$

Dan yang terpenting adalah bahwa poligami bukanlah barang terlarang. Poligami sekali-kali tidak bertujuan untuk merendahkan derajat kaum perempaun, dan juga tidak sekedar memperturutkan hawa nafsu

${ }^{25}$ Iman Rachman, Islam Jawaban Semua Masalah Hidup; Renungan untuk keluarga sakinah, (Jakarta: Penerbit Erlangga, 2011), h. 115.

${ }^{26}$ Ibid, h, 117 .

${ }^{27}$ Ibid, h. 137 
116-122 | Nasruddin \& Ach Zulfikar Ali

kaum laki-laki, makanya orang-orang yang hendak melakukan poligami dipersyaratkan hal-hal yang tidak sederhana. ${ }^{28}$ Namun bagi yang memusuhi Islam memang menargetkan para kaum muslimah, terutama yang kurang memiliki pengetahuan agama Islam, mula-mula memancing mereka mempertanyakan kebenaran ajaran Islam sampai kemudian membawa mereka untuk mengingkarinya.

Sesuai dengan dialog film tersebut, mempertontonkan kepada penonton bahwa permasalahan jilbab dan poligami seolah-olah sangat runcing perdebatannya dikalangan umat Islam. Padahal sejatinya tidak. Dengan meruncingkan permasalahan tersebut ke ranah publik melalui adegan film, walaupun pada hakikatnya kisah dalam film tersebut merupakan kisah pengalaman pribadi. Paling tidak ingin menampilkan sesungguhnya apa yang sedang dihadapi oleh umat Islam Islam di Eropa.

Dengan cara mengumbar tuduhan bahwa Islam membawa ajaran merendahkan derajat kaum perempuan. Bahkan lebih jauh lagi mereka berprasangka buruk bahwa ajaran Islam dikatakan sangat mengekang kaum muslimah, terutama dalam hal berpakaian dan berprilaku. Sungguh semua apa yang mereka sangkakan itu tidak benar.Tuduhan yang lontarkan diharapkan membuat kaum muslimah meragukan kebenaran agama Islam, sehingga keyakinannya goyah dan mau menerima paham dan kepercayaan lain selain Islam seperti paham femenisme.

Demikian halnya juga dengan permasalahan poligami, ada yang menganggap poligami sebagai tren gaya hidup. Seseorang baru bisa dibilang hebat kalau sudah mampu memiliki istri simpanan. Para pelaku poligami begitu mudahnya memutarbalikkan makna ayat-ayat Allah dan sunah Nabi SAW, padahal ini yang diharapkan oleh musuh-musuh Islam agar umat Islam dapat dicitrakan sebagai umat mempertuhankan Syahwat semata.

\section{Scene 9- Permasalahan model jilbab punuk unta}

Pada scene ini adalah bagian dari nilai-nilai deskonstruktif merupakan gambar yang didokomentasikan oleh peneliti dari berbagai adegan film terkait dengan mode jilbab yang dikenakan oleh pemeran film

${ }^{28}$ ibid 
Nasruddin \& Ach Zulfikar Ali: Pesan Dakwah dalam Film | 117-122 yang bermodel punuk unta

Baik di film part 1 dan part 2 dari film 99 cahaya di langit Eropa beberapa pemeran film dari kalangan perempuan memang terlihat sangat anggun memakai jilbab. Dan Jika diperhatikan dengan seksama, sekilas memang pesan pesan non verbal yang disampaikan juga sangat elegan, seperti yang dilihat dibeberapa gambar diatas. Sehingga bisa apa yang ditampilkan di adegan film dapat mudah di amati dan tidak menutup kemungkinan juga ditiru oleh para penonton.

Namun ada hal yang sangat penting yang harus disadari oleh seorang penonton dan penikmat film, mereka harus benar benar teliti dan kritis terhadap apa yang di tontonnya sehingga apa yang ditontonnya tidak membawa nilai-nilai yang justru menjauhkan mereka dari nilai nilai Islam yang murni.

Selanjutnya, Jika diperhatikan mode jilbab yang dimaksud oleh peneliti (terdapat lingkaran merah) terlihat mode jilbab yang ditampilkan di hampir seluruh adegan film tersebut, bermodel tidak sesuai dengan syariat Rasulullah (dikarenakan apa yang model jilbab yang ditampilkan dalam film tersebut menyerupai punuk unta yang dimaksud rasulullah dalam haditsnya.

Rasulullah bersabda:

adaduagolongan penduduknerakayang belum akumelihatkeduanya, (1). Kaum yang membawa cemeti seperti ekor sapi untuk mencambuk manusia (maksudnya penguasa dzalim) dan (2) perempuan-perempuan yang berpakaian tapi telanjang. Cenderung kepada kemaksiatan dan membuat orang lain juga cenderung kepada kemaksiatan. Kepala-kepala mereka seperti punuk-punuk unta yang berlenggak-lenggok. Mereka tidak masuk surga dan tidak mencium bau wanginya. Padahal bau wangi syurga itu tercium dari jarak perjalanan sekian dan sekian waktu (jarakjauh sekali), (HR. Muslim)

Jilbab model punuk unta semakin hari tampak semakin menjadi trend. Salah satu penyebab boomingjilbab punuk unta ini adalah karena para artis mengenakannya juga karena model-model terbaru jilbab mendesainnya demikian. Sehingga sangat digemari oleh para wanita. Sehingga banyak muslimah berjilbab dengan model punuk unta ini, dan 
118-122 | Nasruddin \& Ach Zulfikar Ali

hal itu sangat mudah dijumpai di berbagai tempat. Mereka biasanya menggulung rambutnya dibagian belakang kepala, bahkan dibagian belakang atas kepala sehingga ada benjolan persis penuk unta. Sangat disayangkan model semacam ini meski terlihat elegan dan kekinian tapi ternyata tidak ada anjuran dari rasulullah, bahkan sebaliknya rasulullah sangat mengecam model jilbab semacam itu.

\section{Penutup}

Dari pengamatan yang dilakukan pada Film 99 Cahaya di Langit Eropayang menggunakan analisis semiotika Roland Barthes dengan Fokus penelitian pada rangkaian gambar, dialog, karakter pemeran, visualisasi dan akting dapat diambil kesimpulan sebagai berikut:Terdapat beberapa pesan- dakwah yang ada dalam film 99 cahaya di langit Eropa yaitu: Pesanpesan dakwah pokok yaitu akidah, syariah, dan akhlak.

Pesan akidah terdapat Scene 1 yang menceritakan tentang masalah pentingnya menjaga keimanan dan larangan makan daging babi, pada Scene2 menekankan pesan agar selalu bertawakkal, dan Scene di tabel 3 menceritakan pesan tentang penting peranan hidayah Allah dalam dakwah

Pesan syari'ah terdapat di Scene 4 yang menceritakan pesan pentingnya berjilbab dan menyuruh anak perempuan untuk menutup aurat/berjilbab.

Pesan akhlak terdapat pada Scenesyang menceritakan tentang pentingnya membalas kejahatan orang lain dengan kebaikan. Pada Scene6 menceritakanagar selalu berbuat baik kepada tetangga. Pada Scene 7 menceritakan tentang pentingnya pesan bersedekah dan saling berbagi baik sesama muslim maupun non muslim

Selain itu juga Terdapat pesan dakwah tentang cara beragama kontemporer sebagaimana yang dijelaskan pada scene 8, yaitu tanggapan atas serangan orang non muslim terkait jilbab dan poligami serta sebuah kritikan terhadap pesan non verbal yang kontradiksi dengan pesan dakwah dalam film itu sendiri Perihal model jilbab punuk unta yang dipakai oleh pemain film. 
Nasruddin \& Ach Zulfikar Ali: Pesan Dakwah dalam Film | 119-122

\section{Daftar Pustaka}

Abdul Baqi, Muhammad Fuad, Shohih Muslim Jilid 4,Cet. 1, Jakarta: Pustaka As-Sunnah, 2010)

Abrori, Representasi Pesan Komunikasi dakwah dalam Film Habibi \& Ainun (Studi Semiotika Pesan Komunikasi Dakwah dalam Film Habibi \& Ainun) (Skripsi IDIA Prenduan, 2014).

'Afifi, Abdullah Thaha, 120 Kunci Surga dari Qur'an \& Sunnah, Cet. 10, Jakarta: Gema Insani, 1994.

al-Ḥasan̄̄, al-Sayyid Muḥammad 'Alawī al-Mālikī, Huwa Allāh (Mekkah:

Hai'ah al-Șafwah Al-Mālikiyah, tanpa tahun terbit.

. Al-Qudwah al-Hasanah fi Manhaj al-Da'wah, Terj. Samsul Munir Amin., Cet.(Jakarta, 2oo6).

Al-Hasyimi, Mun'im Abdul, Akhlak Rasul Menurut Bukhari\&Muslim, Cet. 4 Jakarta; Gema Insani, 2013.

As-Shabuni Ali, Shafwatut Tafasir (Tafsir-tafsir Pilihan) jilid 3, Cet. 1 Jakarta Timur: Pustaka Al-Kautsar, 2001.

Aziz, Ali Moh, Ilmu Dakwah, Jakarta: Prenamadia Group, 2015.

Az-Zuhaili Wahbah, EnsiklopediAKhlak Muslim dalambermasyarakat, Cet. 1, Bandung, Noura Book.

, Ensiklopedi Akhlak Muslim; Berakhlak kepad Sang pencipta, Cet. 1, Jakarta: Mizan Media Utama, 2013.

Daryani, Pesan Moral Islami dalam Film Habibi dan Ainun (Analisis Semiotika Roland Barthes), (Skripsi UIN Sunan Kalijaga, 2015).

Effendy, Uchjana Onong, Kamus Komunikasi, Bandung: Mandar Maju, 1989. . Ilmu Komunikasi; Teoridan Praktek. Bandung: PT. Remaja

Rosdakarya, 2009

Faizah \& Effendi Muchsin Lalu. Psikologi Dakwah. Jakarta: Prenada Media, 2006.

Farid Ahmad, Syarah Akidah Ahlus-Sunnah Wal-Jama'ah, Solo: Fatiha Publishing, 2016.

G. Dennis Fitryan, Bekerja Sebagai Sutradara, Jakarta: Penerbit Erlangga, 2008. 
120-122 | Nasruddin \& Ach Zulfikar Ali

Hamka, Tafsir Al-AzharJuz 7, 8, dan 9, Jakarta: Pustaka Panjimas, 1983. , Tafsir Al-Azhar Jilid 1, Jakarta: Gema Insani, 2015

Hasan Al-Banna dan Imam Nawawi, Al-Ma'tsurat \& Hadits Arba'in, Cet. 7, Jakarta: Gema Insani 2007.

Indonesia, Kementerian Agama Republik, Qur'an Hafalan, (Jakarta: Halim, 2013).

Ikhwanto, Nilai-nilai Pendidikan dalam Film Ayat-Ayat Cinta karya Hanung Bramantyo (Skripsi UIN Sunan Kalijaga, 20o9).

Ismail Ilyas \& Hotman Prio, Filsafat Dakwah; Rekayasa Membangun Agama dan Peradaban Islam. Jakarta: Prenada media Gruop, 2011.

Kafi Jamaluddin, Ilmu Dakwah, Sumenep: Al-Amien Printing; 1999.

Khafidhoh, Analisis Film Dalam Mihrob Cinta menurut Perspektif Dakwah Islam (Skripsi IAIN Walisongo, 2012).

Litteljohn W. Stephen \& Foss A Karen. Teori Komunikasi, Jakarta: Salemba Humanika, 2009.

Luthfi Atabik, Tafsir Tazkiyah; Tadabbur Ayat-ayat untuk pencerahan \& penyucian hati, Cet. 1, Depok: Gema Insani, 2009.

Manan, Abdul \& Qulub A Syaiful.Pendidikan Agama Islam UntukPendidikan Perguruan Tinggi. Sidoarjo: Laros, 2010.

Morissan. Teori Komunikasi Individu Hingga Massa. Jakarta: Kencana Prenada Media Group, 2013

Mulyana Deddy \& Rakhmat Jalaludin, Komunikasi Antar Budaya; Panduan Berkomunikasi Dengan Orang-orang Yang Berbeda Budaya, Bandung: PT. Remaja Rosdakarya, 2006.

Mubarok Achmad, Psikologi Dakwah, Jakarta: Pustaka Firdaus, 2001.

Mulyana Deddy. Komunikasi Efektif; Suatu Pendekatan Lintas Budaya. Bandung: PT Remaja Rosdakarya, 2008.

Munandar Haris \& Priatna Dudy, Media Massa \& Masyarakat Modern. Jakarta:Prenada Media.

Nata, Abuddin. Akhlak Tasawuf. Jakarta: PT. Rajagrafindo Persada, 1996.

Nawawi, Syauqi Rif'at, Kpribadian Qur'ani, Jakarta: Amzah, 2014.

Nazir, Moh. Metode Peneltian. Bogor: Ghalia Indonesia, 2014.

Nuruddin, Pengantar Komunikasi Massa, Jakarta: PT Rajagrafindo Persada, 
Nasruddin \& Ach Zulfikar Ali: Pesan Dakwah dalam Film | 121-122 2014.

Purnamawati Sri, Teknik Pembuatan Film, Surabaya: Iranti Mitra Utama, 2009.

Sobur Alex. Semiotika Komunikasi, Bandung: PT. Remaja Rosdakarya, 2006 Syah Hakim, Dakwah Dalam Film di Indonesia (Jurnal Dakwah UIN Sunan Kalijaga Vol. XIV No.2 Tahun 2013).

Shihab M. Quraish, Tafsir Al-Misbah; Pesan, Kesan, dan Keserasian Al-Quran Volume 4, Cet. V, Jakarta: Lentera Hati, 2012.

Tim Penyusun. Pedoman Penulisan Karya Ilmiah; Makalah, Artikel dan Skripsi. IDIA, 2016.

Ramadan Tariq, Teologi; Dialog Islam Barat, Bandung: Mizan, 2002.

Rokhmansyah, Alfin, Studi dan Pengkajian Sastra; Perkenalan awal terhadap Ilmu Sastra, (Yogyakarta: Graha Ilmu, 2014).

West Richard \& Turner H. Lynn. Teori Komunikasi; Analisis dan Aplikasi. Jakarta: Salemba Humanika, 2008.

\section{REFERENSI DARI INTERNET}

Wikipedia. https://id.wikipedia.org/wiki/99_Cahaya_di_Langit_Eropa_ (film) diakses pada tanggal 31 Oktober 2016 M.

http://www.wowkeren.com/berita/tampil/ooo44256.html\#ixzz4aSbBIX3x

Di Akses Pada tanggal o5 Maret 2017

http://www.republika.co.id/berita/senggang/film/13/11/29/mxoyolmenikmati-sejarah-Islam-lewat-9g-cahaya-di-langit-Eropa' diakses pada tanggal o5 Maret 2017

http://hot.detik.com/art/273636g/novel-g9-cahaya-di-langit-Eropa-raihpenghargaan-book-of-the-yearo diakses pada tanggal o5 Maret 2017 http://sinthiasinor.blogdetik.com/2011/o7/17/tentang-film/ diakses pada tanggal o7 Maret 2017

https://muslim.or.id/5401-hidayah-milik-allah.html diakses tangggal o4 April 2017 Jam 21:31 